UDC 631.349 .2

LBC 44.9

\title{
APPLICATION OF BIOPREPARATIONS ON THE BASIS OF CHITOZAN IN AGRICULTURE
}

\author{
Yuliya A. Zimina \\ Volgograd State University, Volgograd, Russian Federation \\ Galina A. Sroslova \\ Volgograd State University, Volgograd, Russian Federation \\ Margarita V. Postnova \\ Volgograd State University, Volgograd, Russian Federation
}

\begin{abstract}
The widespread use of chemical fertilizers and plant protection products causes a serious imbalance in the environment and has an adverse effect on human health. Therefore, the study of the possibility of using safe bio-fertilizers is a very urgent task. This article provides an overview of research studies on the properties of chitosan that are of interest for use in agriculture.

Chitosan, a natural compound that is made from the shells of marine organisms. Currently, a large number of studies are devoted to the study of the properties of chitosan, which protect crops from pathogens, as well as various abiotic stresses. It is established that chitosan effectively improves the physiological properties of plants, and also increases the shelf life of fruits. Chitosan is of interest as an additive to the soil as a nutrient that increases the efficiency of chemical fertilizers and does not affect the beneficial soil microbiota. In addition, chitosan increases the protective functions of plants at the genetic level.

Key words: chitosan, chitin, agriculture, plant protection, bio-fertilizer, abiotic and biotic stress, nanotechnology.
\end{abstract}

УДК 631.349 .2

ББК 44.9

\section{ПРИМЕНЕНИЕ БИОПРЕПАРАТОВ НА ОСНОВЕ ХИТОЗАНА В СЕЛЬСКОМ ХОЗЯЙСТВЕ \\ Юлия Александровна Зимина}

Волгоградский государственный университет, г. Волгоград, Российская Федерация

Галина Алексеевна Срослова

Волгоградский государственный университет, г. Волгоград, Российская Федерация

\section{Маргарита Викторовна Постнова}

Волгоградский государственный университет, г. Волгоград, Российская Федерация

Аннотация. Широкое использование химических удобрений и средств защиты растений вызывает серьезный дисбаланс в окружающей среде и оказывает неблагоприятное воздействие на здоровье человека. В связи с этим изучение возможности применения безопасных биоудобрений является весьма актуальной задачей. В данной статье представлен обзор научных исследований, посвященных изучению свойств хитозана, представляющих интерес для использования в сельском хозяйстве.

Хитозан, природное соединение, которое производится из раковин морских организмов. В настоящее время большое количество исследований посвящено изучению свойств хитозана, обеспечивающих защиту 
сельскохозяйственных культур от болезнетворных микроорганизмов, а также различных абиотических стрессов. Установлено, что хитозан эффективно улучшает физиологические свойства растений, а также увеличивает срок хранения плодов. Хитозан представляет интерес как добавка к почве в качестве питательного вещества, повышающая эффективность химических удобрений и не влияющая на полезную микробиоту почвы. Кроме того, хитозан повышает защитные функции растений на генетическом уровне.

Ключевые слова: хитозан, хитин, сельское хозяйство, защита растений, биоудобрение, абиотический и биотический стресс, нанотехнологии.

Введение. В последнее время хитозан является одним из наиболее широко изучаемых и используемых биополимеров благодаря его биосовместимости, антиоксидантным, противораковым, биоразлагаемым, антимикробным и нетоксичным свойствам. Целесообразность его применения также обусловлена тем, что сырьем для его производства является экономичный материал, полученный из отходов - оболочек морских организмов $[1,2]$. Помимо сельского хозяйства, хитозан находит широкое применение также в пищевой, косметической, текстильной и биомедицинской промышленности $[8,9,10,12]$.

Хитозан является $\mathrm{N}$-деацетилированным производным хитина (основного структурного полимера, составляющего большую часть насекомых и экзоскелет ракообразных). По своей химической структуре хитозан представляет собой линейный полимер, природный полисахарид, состоящий из двух субъединиц, таких как D-глюкозамин и Nацетил-D-глюкозамин, связанных между со-

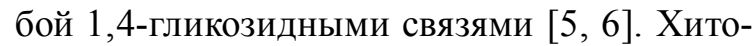
зан получают из хитина в промышленном масштабе. Хитин экстрагируют, следуя классическому кислотно-щелочному методу. Далее осуществляют деминерализацию с использованием кислот с последующей депротеинизацией. [4, 7]. Присутствие аминогрупп в составе хитозана делает его склонным к структурным изменениям [11].

\section{Повышение устойчивости растений} по отношению к биогенным факторам среды. Хитозан является биофунгицидом, биобактерицидом и биовируцидом, тем самым обеспечивая защиту растений от патогенных микроорганизмов, что привлекает внимание исследователей в области защиты растений $[13,16,20]$. Первое исследование использования хитозана в качестве антипатогена у растений было описано Алланом и Хадвигером [16], где они продемонстрировали фунгицидное действие хитозана на различные виды грибковых заболеваний растений. Проявление защитной функции при применении хитина и хитозана наблюдалось также в отношении однодольных, и двудольных растений [17]. Хитозан оказывает положительное влияние на рост ризобактерий, тем самым укрепляя их симбиотическую связь с растениями. Следствием этого является повышение скорости прорастания и улучшение усвоения питательных веществ растениями [21].

Большой вред сельскохозяйственным растениям наносят вирусы. Таким образом, использование хитозана в качестве вирулицида считается целесообразным способом ограничения вирусной инфекции [15]. Результаты исследований по применению хитозана для защиты картофеля, зараженного вирусом X (PVX), показали повышение устойчивости данного растения к вирусу [16]. При изучении защитных свойств хитозана по отношению к растениям томата было выявлено не только проявление устойчивости к вирусу томатной мозаики, но и улучшение их вегетативного роста [19]. Так же хитозан повышает устойчивость к вирусу скручивания листьев у растений томата и оказывается эффективным против вируса мозаики Сквоша (SMV) [22].

Таким образом, в научной литературе представлено большое количество результатов исследований, посвященных использованию хитозана в борьбе с болезнями растений, вызываемыми микрорганизмами. В то же время существует недостаток информации об активности хитозана по отношению нематодам, а также по отношению к насекомым-вредителям, поэтому необходимы дальнейшие исследования для оценки роли хитозана как потенциального нематоцида и инсектицида.

Повышение устойчивости растений по отношению к абиогенным факторам среды. Исследования показывают, что хитозан можно использовать в качестве биости- 
мулятора растительной иммунной системы для борьбы с различными неблагоприятными условиями окружающей среды. Стресс, вызванный засухой, является одним из наиболее важных многомерных факторов, которые наносят ущерб физиологии, биохимическим и молекулярным свойствам растений [23]. Например, у яблонь молодые проростки опрыскивали препаратом хитозана, который усиливал антиоксидантную активность и восстанавливал содержание влаги при продолжительном стрессе от засухи. Хитозан также индуцировал устойчивость к стрессу, вызванному засухой, у таких растений как, картофель, орхидеи, рис, белый клевер и виноград. Один из выявленных защитных механизмов заключается в повышении активности абсцизовой кислоты, которая играет ключевую роль в регуляции устьичного отверстия и снижает скорость транспирации, когда растение переживает стрессовую фазу [14, 24]. Имеются предположения, что хитозан может быть потенциальным антитранспирантом, который помогает сельскохозяйственным растениям справляться со стрессом, вызванным засухой.

Такой фактор окружающей среды как тепловой стресс, усугубляет воздействие засухи, что представляет собой особую проблему для сельскохозяйственных культур [3]. При выращивании бобовых растений в условиях теплового стресса хитозановая обработка является способом избежать гибели поздних всходов растений $[25,28]$. Однако, данный вопрос отражен в научной литературе не достаточно полно и требует дальнейшего исследования.

Повышение устойчивости растений на генетическом уровне. Хитозан играет роль в регуляции экспрессии генов и стимулировании систем молекулярной защиты у растений. Экспрессия генов - это биологический процесс, который зависит от изменения окружающей среды и позволяет клеткам реагировать на внешние раздражители. Существует ряд исследований, посвященных участию хитозана в экзогенной регуляции экспрессии генов [27, 28, 29]. Хитозан ингибирует синтез РНК в грибах путем активации несколько генов и увеличения выработки белков и фенольных соединений через фенилпропаноидный путь, что, в свою очередь, защищает культурные растения от патогенов [30]. PR-гены индуцируются хитозаном. Хитиназа (ЕС 3.2.1.14) и в-1,3-глюканаза (EC 3.2.1.39) - белки PR, способствуют защите растений от грибковой инфекции, разрушая клеточную стенку микроорганизмов [26].

В растениях томата экстракты хитозана использовались для смягчения воздействия двух томатных патогенов, а именно Alternaria solani и Xanthomonas vesicatoria. Выводы, сделанные на основании иследований предполагают, что хитозан значительно усиливает экспрессию маркера PINII, который отвечает за активацию защитных сигнальных путей. Было также обнаружено, что в растениях перца, малины и клубники хитозан эффективен для стимулирования механизмов защиты растений из-за более высокого уровня экспрессии генов хитиназы и в-1,3-глюканазы. У винограда, предварительно обработанного хитозаном из трех различных коммерчески выпускаемых составов, была обнаружена показали более высокая активность эндохитиназы, а два из рассмотренных составов хитозана вызвали активность экзохитиназы. Тем не менее, все еще мало изучен вопрос о влиянии хитозана на гены PR при различных стрессах. Так, например, гены Mildew-Locus-O (MLO) в овощных культурах способствуют восприимчивости к возбудителю болезни мучнистой росы. Таким образом, необходимы исследования для оценки влияния хитозана на экспрессию гена MLO.

Нанотехнологии при применении хитозана. Иммуномодулирующая роль хитозана, уже была продемонстрирована на растениях, в то время как его наночастицы были исследованы только для биомедицинских целей. Были изучены способность и механизм наночастиц хитозана индуцировать и усиливать иммунные ответы у растений [31]. Обработка листьев данным препаратом привела к значительному улучшению иммунного ответа растения за счет повышения активности защитных ферментов, активации генов, связанных с защитой, а также повышения концентрации фенольных соединений. Оксид азота (NO), важная сигнальная молекула в защите растений. Его образование также увеличивается после обработки наночастицами хитозана. 
Заключение. Анализ научных публикаций показал, что у хитозана, как у уникального продукта, доступного в больших количествах и по низкой цене, большое будущее в развитии устойчивых методов ведения сельского хозяйства. Хитозан является перспективным инструментом для выращивания растений в условиях биотического и абиотического стресса. Хитозан и его производные обеспечивают хорошую противомикробную активность, не нарушая полезную микрофлору почвы, что может рассматриваться как зеленый подход к стерилизации почвы. Следовательно, необходимы дальнейшие исследования возможности использования хитозана против теплового стресса, для предотвращения повреждений растений и плодов, вызванных нематодами и насекомыми, и, как следствие, для сокращения чрезмерного использования синтетических удобрений и средств защиты растений в сельском хозяйстве.

\section{СПИСОК ЛИТЕРАТУРЫ}

1. Бороздина, Н.А. Сорбционные свойства билиарных хитазановых стентов / Н.А. Бороздина // Материалы научной сессии. Сборник материалов в 6 частях. - Волгоградский государственный университет. - 2016. - С. 6-8.

2. Бороздина, Н.А. Разработка метода изготовления и использования хитозановых пленок / Н.А. Бороздина, Т.А. Кобальнова, А.С. Рыгалов // Экологические, генетические, биотехнологические проблемы и их решение при производстве и переработке продукции животноводства. Материалы международной научно-практической конференции (посвященная памяти академика РАН Сизенко Е.И.). - 2017. - С. 347-350.

3. Иванцова, Е.А. Результаты применения биологически активных веществ в плодовом саду / Е.А. Иванцова, А.А. Федосов // Известия Нижневолжского агроуниверситетского комплекса: Наука и высшее профессиональное образование. - 2009. № 3. - C. 21-25.

4. Картавченко, В.В. Региональная промышленная политика: Формирование, проблемы реализации / В.В. Картавченко, О.А. Минаева, Г.С. Мерзликина, И.В. Пшеничников и др. // Волгоград-2014. - С. 176-178.

5. Коваленко, А.В. Саморасширяющиеся хитозановые стенты: технология изготовления / А.В. Коваленко, В.В. Шинкарев, Н.А. Бороздина // Вестник
Волгоградского государственного университета. Серия 11: Естественные науки. - 2016. - №1 (15). C. 26-32.

6. Способ получения хитозана / М.П. Лябин, В.В. Новочадов, П.С. Семенов // Патент 2539933, МКП С 08 37/08-2015.

7. Мерзликина, Г.С. Инновационный потенциал региона: формирование и стратегия развития / Г.С. Мерзликина, А.В. Бабкин, И.В. Пшеничников // Вестник Астраханского государственного университета. Серия. Экономика. -2015. - № 3. - С. 99-109.

8. Мулик, А.Б. Разработка методологических и методических подходов к персонализации формирования токсических нагрузок на организм человека / А.Б. Мулик, Ю.А. Шатыр, М.В. Постнова // Mebline. Российский биомедицинский журнал 2015. - T. 16. - № 2. - C. 456-474.

9. Allan, C.R. The fungicidal effect of chitosan on fungi of varying cell wall composition / C.R. Allan, L.A. Hadwiger // Exp. Mycol. - 1979. - pp. 285-287.

10. Barber, M. Chitin oligosaccharides elicit lignification in wounded wheat leaves. / M. Barber, R. Bertram, J. Ride // Physiol. Mol. Plant Pathol. 1989. - pp. 3-12.

11. Bondok, A. Response of Tomato Plants to Salicyli c Acid and Chitosan under Infection with Tomato mosaic virus. / A. Bondok // Am.-Eur. J. Agric. Environ. Sci. - 2015. - pp. 1520-1529.

12. Chandra, S. Chitosan-induced immunity in Camellia sinensis / S. Chandra, N. Chakraborty, K.Panda, K. Acharya // Kuntze against blister blight disease is mediated by nitric-oxide. Plant Physiol. Biochem. - 2017. - № 115. - pp. 298-307.

13. Chirkov, S. Effect of chitosan on systemic viral infection and some defense responses in potato plants / S. Chirkov, A. Il'ina, N. Surgucheva, E. Letunova, Y.A. Varitsev, N.Y. Tatarinova, V. Varlamov // Russ. J. Plant Physiol. - 2001. - pp. 774-779.

14. Choi, Y.-S. Overexpression of ArabidopsisABF3 gene confers enhanced tolerance to drought and heat stress in creeping bentgrass / Y.-S. Choi, Y.-M. Kim, O.-J. Hwang, Y.-J. Han, S.Y. Kim, J.-I. Kim // Plant Biotechnol. Rep. - 2013. - pp.165-173.

15. Dash, M. A versatile semi-synthetic polymer in biomedical applications / M. Dash, F. Chiellini, R. Ottenbrite, E. Chiellini // Chitosan Prog. Polym. Sci. 2011. - pp. 981-1014.

16. Dodgson, J. L.A. Comparison of effects of chitin and chitosan for control of Colletotrichum sp. on cucumbers / J. L.A. Dodgson, W. J. Dodgson // Pure Appl. Microbiol. -2017. - 11. - pp. 87-93.

17. El-Mohamedy, R.S.R. Field application of plant resistance inducers (PRIs) to control important root rot diseases and improvement growth and yield of green bean (Phaseolus vulgaris L.) / R.S.R. ElMohamedy, M.R. Shafeek, E.E.-D.H.Abd El-Samad, 
D.M. Salama, F.A. Rizk // Aust. J. Crop Sci. - 2017. 11.pp. 496-505.

18. Faoro, F. Induced Systemic Resistance against Systemic Viruses: A Feasible Approach? / Faoro F. // -2018. - pp. 345.

19. Firmansyah, D. Use of Chitosan and Plant Growth Promoting Rhizobacteria to Control Squash Mosaic Virus on Cucumber / D. Firmansyah // Plants. Asian J. Plant Pathol. - 2017. - pp. 567-573.

20. Gumilar, T.A. Utilization of waste silica and chitosan as fertilizer nano chisil to improve corn production in Indonesia / T.A. Gumilar, E. Prihastanti, S. Haryanti, A. Subagio, A. Ngadiwiyana // Adv. Sci. Lett. - 2017. - no. 23. - pp. 2447-2449.

21. Hadwiger, L.A. Multiple effects of chitosan on plant systems: Solid science or hype / L.A. Hadwiger // Plant Sci. -2013. - pp.42-49.

22. Ibrahim, E.A. Effect of zinc foliar spray alone and combined with humic acid or/and chitosan on growth, nutrient elements content and yield of dry bean (Phaseolus vulgaris L.) / E.A. Ibrahim, W.A. Ramadan // plants sown at different dates. Sci. Hortic. - 2015. pp. 101-105.

23. Iriti, M. Abscisic acid is involved in chitosaninduced resistance to tobacco necrosis virus (TNV) / M. Iriti, F. Faoro // Plant Physiol. Biochem. - 2008. pp.1106-1111.

24. Kaya, M. Fluctuation in physicochemical properties of chitins extracted from different body parts of honeybee / M. Kaya, M. Mujtaba, E. Bulut, B. Akyuz, L. Zelencova, K. Sofi // Carbohydr. Polym. - 2015.pp. 9-16.

25. Kiprushkina, E.I. Protective-stimulating properties of chitosan in the vegetation and storing tomatoes / E.I. Kiprushkina,; I.A. Shestopalova, A.M. Pekhotina, E.E. Kuprina, O.V. Nikitina // Prog. Chem. Appl. Chitin Deriv. - 2017. - no. 23. - pp. 77-81.

26. Li, B. Effect of chitosan solution on the inhibition of Acidovorax citrulli causing bacterial fruit blotch of watermelon. / B. Li, Y. Shi, C. Shan, Q. Zhou, M. Ibrahim, Y. Wang, G. Wu, H. Li, G. Xie, G. Sun // J. Sci. Food Agric. - 2013. - pp. 1010-1015.

27. Mwaheb, M.A.M.A. Synergetic suppression of soybean cyst nematodes by chitosan and Hirsutella minnesotensis via the assembly of the soybean rhizosphere microbial communities / M.A.M.A. Mwaheb, M. Hussain, J. Tian, Zhang Xiaoling, X.; Imran Hamid, Abo El-Kassim et all // Biol. Control. 2017-115. - pp. 86-94.

28. Rinaudo, M. Chitin and chitosan: Properties and applications / Rinaudo M. // Prog. Polym. Sci. 2006. - pp. 603-632.

29. Salehi-Lisar, S.Y. Drought Stress Tolerance in Plants / S.Y. Salehi-Lisar, H. Bakhshayeshan-Agdam // Drought Stress in Plants: Causes, Consequences, and Tolerance. - 2016. - pp.1-16.
30. Shamov, M. Interaction of carboxylic acids with chitosan: Effect of $\mathrm{pK}$ and hydrocarbon chain length / M. Shamov, S.Y. Bratskaya, V. Avramenko // J. Colloid Interface Sci. - 2002. - pp. 316-321.

31. Shukla, S.K. Chitosan-based nanomaterials: A state-of-the-art review/ S.K. Shukla, A.K. Mishra, O.A. Arotiba, B.B. Mamba // Int. J. Biol. Macromol. 2013. - pp. 46-58.

\section{REFERENCES}

1. Borozdina N.A. Sorbcionnye svojstva biliarnyh hitazanovyh stentov [Sorption properties of biliary chitazan stents]. Materialy nauchnoj sessii. Sbornik materialov v 6 chastjah. - Volgogradskij gosudarstvennyj universitet, 2016, pp. 6-8.

2. Borozdina N.A, Kobal'nova T.A., Rygalov A.S. Razrabotka metoda izgotovlenija i ispol'zovanija hitozanovyh plenok [Development of a method for the manufacture and use of chitosan films]. Jekologicheskie, geneticheskie, biotehnologicheskie problemy i ih reshenie pri proizvodstve i pererabotke produkcii zhivotnovodstva. Materialy mezhdunarodnoj nauchnoprakticheskoj konferencii (posvjashhennaja pamjati akademika RAN Sizenko E.I.), 2017, pp. 347-350.

3. Ivantsova E.A., Fedosov A.A. Rezultaty primenenia biologicheski aktivnyx vezestv v plodovom sadu [Results of the use of biologically active substances in the orchard]// Izvestija Nizhnevolzhskogo agrouniversitetskogo kompleksa: Nauka i vysshee obrazovanie [News lower Volga agrodiversity complex: Science and higher education], 2009, no 3, pp. 21-25.

4. Kartavchenko V.V., Kartavchenko V.V., Minaeva O.A., Merzlikina G.S., Pshenichnikov I.V. i dr. Regional'naja promyshlennaja politika: Formirovanie, problemy realizacii [Regional industrial policy: Formation, problems of implementation]. Volgograd, 2014,pp. 176-178.

5. Kovalenko A.V. Shinkarev V.V., Borozdina N.A. Samorasshirjajushhiesja hitozanovye stenty: tehnologija izgotovlenija [Self-expanding chitosan stents: manufacturing technology]. Vestnik Volgogradskogo gosudarstvennogo universiteta. Serija 11: Estestvennye nauki, 2016, no. 1(15), pp. 26-32.

6. Sposob poluchenija hitozana / M.P. Ljabin, V.V. Novochadov, P.S. Semenov // Patent 2539933, MKP S 08 37/08, 2015.

7. Merzlikina G.S., Babkin A.V., Pshenichnikov I.V. Innovacionnyj potencial regiona: formirovanie i strategija razvitija [Innovative potential of the region: the formation and development strategy]. Vestnik Astrahanskogo gosudarstvennogo universiteta. Serija. Jekonomika, 2015, no. 3, pp. 99-109.

8. Mulik A.B. Shatyr Ju. A., Postnova M.V. Razrabotka metodologicheskih i metodicheskih 
podhodov k personalizacii formirovanija toksicheskih nagruzok na organizm cheloveka [Development of methodological and methodological approaches to the personalization of the formation of toxic loads on the human body] Mebline. Rossijskij biomedicinskij zhurnal, 2015, T. 16, no.2, pp. 456-474.

9. Allan C.R., Hadwiger L.A. The fungicidal effect of chitosan on fungi of varying cell wall composition. Exp. Mycol., 1979, pp. 285-287.

10. Barber M., Bertram R., Ride J. Chitin oligosaccharides elicit lignification in wounded wheat leaves. Physiol. Mol. Plant Pathol, 1989, pp. 3-12.

11. Bondok A. Response of Tomato Plants to Salicyli c Acid and Chitosan under Infection with Tomato mosaic virus. Am.-Eur. J. Agric. Environ. Sci., 2015, pp. 1520-1529.

12. Chandra S., Chakraborty N., Panda K., Acharya K. Chitosan-induced immunity in Camellia sinensis. Kuntze against blister blight disease is mediated by nitric-oxide. Plant Physiol. Biochem, 2017, no. 115 , pp. 298-307.

13. Chirkov S. Il'ina A., Surgucheva N., Letunova E., VaritsevY.A.,. Tatarinova N.Y, Varlamov V.Effect of chitosan on systemic viral infection and some defense responses in potato plants. Russ. J. Plant Physiol, 2001, pp. 774-779.

14. Choi Y.-S., Kim Y -M, Hwang O.-J., Han Y.-J., Kim S.Y., Kim J.-I. Overexpression of Arabidopsis ABF3 gene confers enhanced tolerance to drought and heat stress in creeping bentgrass. Plant Biotechnol. Rep, 2013, pp.165-173.

15. Dash M., Chiellini F., Ottenbrite R., Chiellini E. A versatile semi-synthetic polymer in biomedical applications. Chitosan Prog. Polym. Sci, 2011, pp. 981-1014.

16. Dodgson J. L.A., Dodgson W. J. Comparison of effects of chitin and chitosan for control of Colletotrichum sp. on cucumbers. Pure Appl. Microbiol, 2017, 11, pp. 87-93.

17. El-Mohamedy R.S.R., Shafeek M.R., Abd ElSamad E.E.-D.H., Salama D.M., Rizk F.A. Field application of plant resistance inducers (PRIs) to control important root rot diseases and improvement growth and yield of green bean (Phaseolus vulgaris L.) . J. Crop Sci., 2017, no. 11, pp. 496-505.

18. Faoro F. Induced Systemic Resistance against Systemic Viruses: AFeasible Approach?, 2018, pp. 345.

19. Firmansyah D. Use of Chitosan and Plant Growth Promoting Rhizobacteria to Control Squash Mosaic Virus on Cucumber. Plants. Asian J. Plant Pathol, 2017, pp. 567-573.
20. Gumilar T.A., Prihastanti E., Haryanti S., Subagio A., Ngadiwiyana A. Utilization of waste silica and chitosan as fertilizer nano chisil to improve corn production in Indonesia. Adv. Sci. Lett., 2017, no. 23, pp. 2447-2449.

21. Hadwiger, L.A. Multiple effects of chitosan on plant systems: Solid science or hype. Plant Sci., 2013, pp.42-49.

22. Ibrahim E.A. Ramadan W.A. Effect of zinc foliar spray alone and combined with humic acid or/ and chitosan on growth, nutrient elements content and yield of dry bean (Phaseolus vulgaris L.). Plants sown at different dates. Sci. Hortic, 2015, pp.101-105.

23. Iriti M, Faoro F. Abscisic acid is involved in chitosan-induced resistance to tobacco necrosis virus (TNV). Plant Physiol. Biochem, 2008, pp.1106-1111.

24. Kaya M., Mujtaba M., Bulut E., Akyuz B., Zelencova L., Sofi K. Fluctuation in physicochemical properties of chitins extracted from different body parts of honeybee. Carbohydr. Polym, 2015, pp. 9-16.

25. Kiprushkina E.I., Shestopalova I.A., Pekhotina A.M., Kuprina E.E., Nikitina O.V. Protectivestimulating properties of chitosan in the vegetation and storing tomatoes. Prog. Chem. Appl. Chitin Deriv, 2017, no. 23, pp. $77-81$.

26. Li B, Shi Y., Shan C., Zhou Q., Ibrahim M., Wang Y., Wu G., Li H., Xie G., Sun G. Effect of chitosan solution on the inhibition of Acidovorax citrulli causing bacterial fruit blotch of watermelon. J. Sci. Food Agric, 2013, pp.1010-1015.

27. Mwaheb M.A.M.A., Hussain M., Tian J., Xiaoling Zhang, Imran X., Hamid, El-Kassim Abo et all Synergetic suppression of soybean cyst nematodes by chitosan and Hirsutella minnesotensis via the assembly of the soybean rhizosphere microbial communities. Biol. Control, 2017, no. 115, pp. 86-94.

28. Rinaudo M. Chitin and chitosan: Properties and applications. Prog. Polym. Sci., 2006, pp. 603-632.

29. Salehi-Lisar, S.Y., Bakhshayeshan-Agdam H. Drought Stress Tolerance in Plants. Drought Stress in Plants: Causes, Consequences, and Tolerance, 2016, pp. 1-16.

30. Shamov M. Bratskaya S.Y., Avramenko V. Interaction of carboxylic acids with chitosan: Effect of $\mathrm{pK}$ and hydrocarbon chain length. J. Colloid Interface Sci, 2002, pp. 316-321.

31. Shukla S.K. Mishra A.K., Arotiba O.A., Mamba B.B. Chitosan-based nanomaterials: A stateof-the-art review. J. Biol. Macromol, 2013, pp. 46-58. 


\section{Information about the Authors}

Yuliya A. Zimina, Candidate of Chemistry Sciences, Associate Professor, Department of Bioengineering and Bioinformatics, Volgograd State University, Prosp. Universitetsky, 100, 400062 Volgograd, Russian Federation, ziminaua@mail.ru.

Galina A. Sroslova, Candidate of Biological Sciences, Associate Professor, Department of Bioengineering and Bioinformatics, Volgograd State University, Prosp. Universitetsky, 100, 400062 Volgograd, Russian Federation, sroslova.galina@volsu.ru.

Margarita V. Postnova, Doctor of science (Biology), Associate Professor, Head of Department of Bioengineering and Bioinformatics, Volgograd State University, Prosp. Universitetsky, 100, 400062 Volgograd, Russian Federation, postnova@volsu.ru.

\section{Информация об авторах}

Юлия Александровна Зимина, кандидат химических наук, доцент кафедры биоинженерии и биоинформатики, Волгоградский государственный университет, просп. Университетский, 100, 400062 г. Волгоград, Российская Федерация, ziminaua@mail.ru.

Галина Алексеевна Срослова, кандидат биологических наук, доцент кафедры биоинженерии и биоинформатики, Волгоградский государственный университет, просп. Университетский, 100, 400062 г. Волгоград, Российская Федерация, sroslova.galina@volsu.ru

Маргарита Викторовна Постнова, доктор биологических наук, заведующий кафедрой биоинженерии и биоинформатики, Волгоградский государственный университет, просп. Университетский, 100, 400062 г. Волгоград, Российская Федерация, postnova@volsu.ru 